\title{
Does Entrepreneurial Orientation Lead to Successful Sustainable Innovation? The Evidence from Chinese Environmentally Friendly Companies
}

\author{
Hongyi Mao ${ }^{1}$, Zongjun Wang ${ }^{2}$ and Lin $\mathrm{Yi}^{2, *}$ \\ 1 School of Business Administration, Guizhou University of Finance and Economics, Guiyang 550025, China; \\ mao@mail.gufe.edu.cn \\ 2 School of Management, Huazhong University of Science and Technology, Wuhan 430074, China; \\ wangzj01@mail.hust.edu.cn \\ * Correspondence: 2019505005@hust.edu.cn
}

\section{check for}

updates

Citation: Mao, H.; Wang, Z.; Yi, L. Does Entrepreneurial Orientation Lead to Successful Sustainable Innovation? The Evidence from Chinese Environmentally Friendly Companies. Sustainability 2021, 13, 10294. https://doi.org/10.3390/su 131810294

Academic Editors: Francisco

J. Sáez-Martínez and

Fernando Almeida

Received: 3 August 2021

Accepted: 10 September 2021

Published: 15 September 2021

Publisher's Note: MDPI stays neutra with regard to jurisdictional claims in published maps and institutional affiliations.

Copyright: (c) 2021 by the authors. Licensee MDPI, Basel, Switzerland. This article is an open access article distributed under the terms and conditions of the Creative Commons Attribution (CC BY) license (https:// creativecommons.org/licenses/by/ $4.0 /)$

\begin{abstract}
This research examines the linkage between entrepreneurial orientation and sustainable innovation. Research shows that the effects of entrepreneurial orientation on the exploitation and exploration of sustainable innovation are significantly positive, whereby absorptive capacity acts in a significant mediating role. The interaction between entrepreneurial orientation and absorptive capacity helps organizations overcome organizational inertia and strengthen the sustainability of innovation. By introducing the absorptive capacity theory and the view of organizational inertia, we have conducted empirical research on 392 Chinese environmentally friendly companies that have passed China's national high-tech enterprise certification. We verified the relevant hypotheses in our framework in a structural model analysis using Mplus. To further look at the interaction terms of potential and realized absorptive capacity, we used PROCESS in SPSS to evaluate the conditional effects of absorptive capacity on coefficient paths between entrepreneurial orientation and the two types of innovation. The results show that entrepreneurial orientation improves the absorptive capacity of organizations, thereby promoting their sustainable innovation. Furthermore, based on the theory of sustainable innovation, we proved the positive impact of realized and potential absorptive capacity on the exploitation and exploration of sustainable innovation. Organizations could balance exploitation and exploration to implement sustainable innovation by adjusting their potential and realized absorptive capacities. Our results can help environmentally friendly organizations adjust the combination of entrepreneurial orientation and absorptive capacity to overcome organizational inertia, manage exploitation and exploration, and implement sustainable innovation.
\end{abstract}

Keywords: sustainable innovation; entrepreneurial orientation; absorptive capacity; exploitation and exploration

\section{Introduction}

In order to obtain sustainable returns and to build environmentally friendly organizations, it is increasingly important to develop sustainable innovation [1]. To adapt to the complex and changeable environment while reconciling economic, environmental, and social goals, organizations need to explore new areas of knowledge [2,3], and this is especially true for high-tech companies, as they are increasingly inclined to adopt multiple forms of innovation. Many researchers believe organizations, to establish sustainable competitive advantages, need to become dualized and carry out both exploitation and exploration [4,5]. Exploitation enriches and expands customer value by deepening the understanding of existing assets, products, and services to provide organizations with incremental innovation opportunities. Exploration absorbs knowledge from outside an organization, develops new products, helps create new customer value, and provides organizations with breakthrough innovation opportunities. Compared with exploitation, exploration carries greater risks 
and unpredictable returns. To strategically carry out sustainable innovation, organizations need to use limited resources effectively [6]. Due to the existence of organizational inertia, organizations may pay more attention to investment in exploitative activities and ignore exploration activities, leading to a dilemma for innovators. Therefore, it is particularly important to understand how to balance the allocation of resources between exploitation and exploration in constructing sustainable innovation.

Sustainable innovation is the reshaping of ideas and processes towards achieving sustained financial, social, and environmental performance [7,8]. It is affected by the internal characteristics of the enterprise in which it is situated, as well as the enterprise's external environment, dynamic capabilities, and other factors [9]. Entrepreneurial orientation also has an accidental relationship with an enterprise's internal characteristics [10]. Covin and Lumpkin (2011) described entrepreneurial orientation as supporting a process of organizational strategy formulation [11]. Entrepreneurial orientation embodies the tendency of an organization to act in an entrepreneurial manner; it represents a typical process of strategy formulation and decision-making. This orientation reflects an enterprise's ability in terms of managing its affairs by taking a proactive approach to change in its competitive environment, thereby gaining a competitive advantage [12]. The entrepreneurial process aiming at sustainable innovation is an organizational learning process that generates and updates relevant knowledge [13]. By obtaining new knowledge through experience or observation, and assimilating this knowledge with existing knowledge, organizations can not only gain sustainable technological advantages but also reduce their negative environmental impacts [14]. Therefore, in organizations' processes of innovation, absorptive capacity is the fulcrum that enables innovation [15].

Studies of organizational inertia point out that the self-reinforcing nature of organizational learning makes organizations more efficient in using existing knowledge, and generates exploitation [16]. Entrepreneurially oriented organizations can quickly accumulate knowledge, and the greater the knowledge in a specific field, the more exploitative activities will emerge [17]. Based on the perspective of absorptive capacity, as organizations pay more attention to environmentally friendly innovation and resource management, organizations believe sustainable innovation stems from strengthening their acquisition and absorption of knowledge while advocating new opportunities that guide customers' needs [18]. They adopt the entrepreneurial orientation of risk-taking and advanced action to increase the effectiveness of innovation, which leads to more exploration. Therefore, the relationship between entrepreneurial orientation and sustainable innovation might be more complicated than previously described. By combining these two perspectives, we will examine the impact of entrepreneurial orientation on sustainable innovation, proposing that entrepreneurial orientations have different effects on the exploitation and exploration of sustainable innovation.

The Chinese government's carbon neutrality targets put forward new requirements for the sustainable innovation of Chinese companies. Through long-term observations of China's environmentally friendly companies, we have found that environmentally friendly companies tend to have a strong entrepreneurial orientation. Still, the ways and degrees of sustainable innovation are quite different [13]. While previous studies have paid little attention to the various mechanisms of how entrepreneurial orientation affects two types of sustainable innovation in China, the current study aims to investigate the complex relationships between entrepreneurial orientation, absorptive capacity, and sustainable innovation. Based on a quantitative study design, we investigated the linkage from entrepreneurial orientation to sustainable innovation via absorptive capacity in 392 Chinese high-tech companies. Entrepreneurial orientation has a positive impact on both realized and potential absorptive capacity, and absorptive capacity in turn has positive effects on both exploitation and exploration. Due to the interaction effect of potential and realized absorptive capacity, organizations could avoid falling into inertia by re-allocating resources and adapting to their changing environments to balance exploitation and exploration [19], thus achieving sustainable innovation. 


\section{Theory Development and Hypotheses}

\subsection{Sustainable Innovation and Entrepreneurial Orientation}

Entrepreneurial orientation, which gives organizations strategic flexibility in turbulent environments, is a top-level strategic framework of innovating, preempting, and risk-taking, intended to redistribute and configure organizations' resources, processes, and strategies to overcome discontinuities in the environment [20]. Previous studies have pointed out that entrepreneurial orientation reflects the tendency of organizations' resource-based entrepreneurial activities [21,22]. Over the years, researchers have tried to understand how entrepreneurial orientation affects corporations' innovation [13]. Some studies provide evidence that the effect of entrepreneurial orientation on sustainable innovation is contingent on different boundary conditions [13]. All dimensions of entrepreneurial orientation significantly and positively impact sustainable innovation [23].

Sustainable innovation, as an organization's integration of new ideas and practices, is affected by existing processes and routines [8,24]. It is the basic driving factor by which organizations adapt to rapid changes and highly competitive environments [25]. In this sense, the exploitation and exploration of sustainable innovation are both subject to organizational structure and constraints on processes, and they may manifest different effects of organizational inertia. To overcome organizational inertia, organizations often enact proactive yet risky innovations in their markets to overcome the stability of products, processes, and policies of organizations, and seek to change the competitive environment [26], as they pursue, discover, and create new opportunities in their decision-making processes to maintain a competitive advantage [27]. Therefore, it is possible that organizational inertia complicates the relations of entrepreneurial orientation and sustainable innovation.

\subsection{Roles of Absorptive Capacity}

Entrepreneurial orientation highlights how to act-that is, the procedures, practices, and decision-making activities that lead to new entry behaviors, including trials of new technologies, grasping market opportunities, and making risky investments [28]. Meanwhile, absorptive capacity suggests a series of organizational routines and processes to acquire, assimilate, transform and utilize knowledge [29]. Studies have confirmed that absorptive capacity, combining existing knowledge and new technologies, plays a significant mediating role between corporate strategic orientation and exploratory activities [30]. Organizations can distribute knowledge quickly in a rapidly changing environment, reinforcing the view that absorptive capacity could play a mediating role in the impact of entrepreneurial orientation on organizational innovations [31], so that organizations have the ability to flexibly use, organize, and manage resources in a dynamic environment [32], and significantly impact sustainable innovation [33].

As a corporate-level strategic approach, entrepreneurial orientation encourages and supports organizations' transformations of absorbed knowledge into value-creating collections of resources [34] in order to seek new organizational growth and opportunities for renewal [35]. Based on the previous study, we propose that entrepreneurial orientation can promote the capabilities and development processes of both potential and realized absorptive capacity, thereby improving sustainable innovation. Potential absorptive capacity is regarded as the ability to acquire and assimilate external knowledge, while realized absorptive capacity contains the transformation and exploitation dimensions of absorptive capacity [29]. We take the view of Zahra and George, because their classification of absorptive capacity could better help us understand how entrepreneurial orientation contributes to different types of innovation [36]. This view informs our research model and the following hypotheses, as shown in Figure 1. 


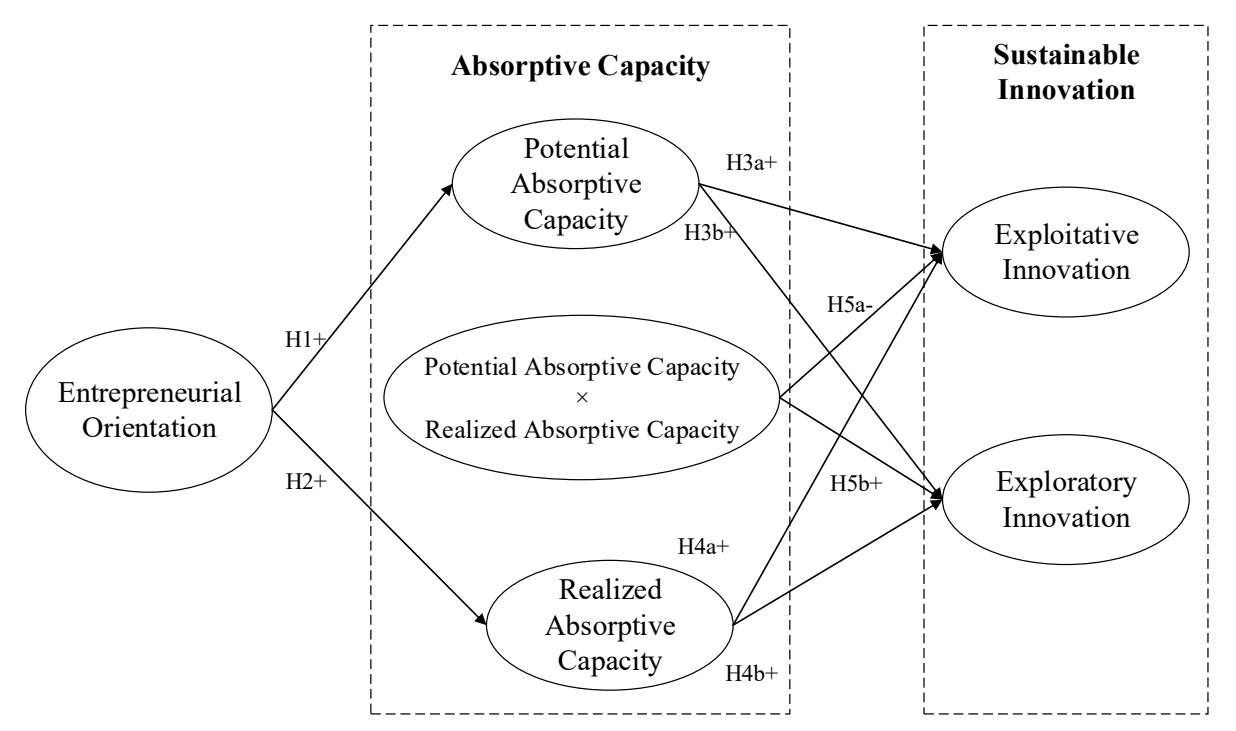

Figure 1. Research model.

\subsection{Entrepreneurial Orientation and Absorptive Capacity}

Entrepreneurial orientation enhances an organization's acceptance of uncertainty and its curiosity in seeking knowledge. It encourages the organization to gather diverse sources of expertise, deepens the horizontal and vertical flows of knowledge, and promotes the organization's unconventional thinking. Information can help organizations deviate from the existing cognitive framework, and it can help units overcome differences, form the ability to assimilate new knowledge and improve its efficient conversion [37]. Furthermore, as entrepreneurial orientation reflects an organization's tendency to make decisions and behaviors regarding new products or services that may be produced, it makes the organization innovative. Given this tendency, the organization may invest more in acquiring and assimilating knowledge and resources [7]. Moreover, entrepreneurial orientation's proactive features make organizations more sensitive to externally acquired knowledge, because organizations can discover trends and opportunities ahead of their competitors, use knowledge-based resources, and implement innovations for potential markets [38]. Therefore, entrepreneurial orientation promotes the acquisition and assimilation of knowledge. This is our first hypothesis.

Hypothesis 1 (H1): Entrepreneurial orientation has a positive correlation with potential absorptive capacity.

Entrepreneurially oriented organizations are often creative about integrating knowledgebased resources; they support self-iteration and are good at seeking the highest possible return from available resources [39]. Entrepreneurial orientation thus encourages organizations to transform, use knowledge to discover new opportunities, and improve their ability to allocate knowledge-based resources with commercial value [40]. Entrepreneurial orientation leads organizations to take risks, to tolerate mistakes, to encourage employees' autonomy, and to support organization members' continuous reflection on existing products and services. This benefits organizations as they integrate new and existing knowledge to create appropriate redundancy. Furthermore, entrepreneurial orientation has the characteristics of competitiveness and an aggressive outlook, promoting an organization's continued attention to the environment, improving the speed and frequency of internal decision-making, and strengthening the organization's adaptability to changes in the environment. Therefore, entrepreneurial orientation promotes the transformation and use of knowledge. This is our second hypothesis. 
Hypothesis 2 (H2): Entrepreneurial orientation has a positive correlation with realized absorptive capacity.

\subsection{Absorptive Capacity and Innovation}

Organizations' sustainable innovation depends on the mechanisms for knowledge management that determine organizational transfer and the use of knowledge [41]. Organizations with a high absorptive capacity look out for opportunities in emerging markets and will be active in exploring new opportunities. In order to carry out sustainable innovation, organizations invest large amounts in areas related to absorptive capacity [42]. This allows them to accelerate their transformation of knowledge into technologies, products, and services. In this process, organizations with strong capabilities in specific fields are more likely to search for more local and proximal knowledge, and to combine existing know-how reserves to initiate improvements in existing processes, improve efficiency, and reduce costs. In this way, a company can obtain a sustainable advantage [17]. Furthermore, as knowledge accumulates, the ability to transform and use external knowledge becomes stronger, enabling the company to reinforce its existing knowledge and give positive feedback between learning and experience [43]. Moreover, in a turbulent external environment, the more efficient conversion and use of knowledge can help organizations adapt more quickly to the requirements of environmental sustainability, promote exploitation, and perform in a reliable manner [44]. Therefore, we hypothesize that absorptive capacity supports exploitative innovation.

Hypothesis 3 (H3a). There are positive relationships between an organization's potential absorptive capacity and its exploitative innovation.

Hypothesis $3 \mathbf{( H 3 b )}$. There are positive relationships between an organization's realized absorptive capacity and its exploitative innovation.

We believe the acquiring, transformation and use of knowledge also has a positive impact on exploration. The efficient acquiring, transferring and using of knowledge can help organizations quickly identify new trends in technology, improving their ability to adopt new technologies [29] and to innovate beyond the boundaries of their current technologies [45]. Meanwhile, the better conversion and use of knowledge can help organizations to more effectively apply new knowledge for business purposes, increasing their certainty in exploratory innovation and enhancing their confidence to continue investing in such innovation. Our fourth hypothesis is as follows:

Hypothesis $4 \mathbf{~ ( H 4 a ) . ~ T h e r e ~ i s ~ a ~ p o s i t i v e ~ r e l a t i o n s h i p ~ b e t w e e n ~ a n ~ o r g a n i z a t i o n ' s ~ p o t e n t i a l ~ a b s o r p t i v e ~}$ capacity and its exploratory innovation.

Hypothesis $4 \mathbf{( H 4 b )}$. There is a positive relationship between an organization's realized absorptive capacity and its exploratory innovation.

Previous studies have confirmed that absorptive capacity affects organizations' paths of exploration and exploitation for sustainable innovation [36]. However, realized and potential absorptive capacity may function differently because potential absorptive capacity focuses on the "inter" perspective of organizational capabilities, while realized absorptive capacity focuses on the "intra" perspective [46,47]. Adjusting through the interaction of realized and potential absorptive capacity enables organizations to balance the tensions generated by exploitation and exploration [48]. Although innovation is the result of organizational transformation and use of knowledge, the organization still needs to update its knowledge structure by assimilating new external knowledge. This is how the internal knowledge structure becomes more complete. Because exploratory innovation requires organizations to stop depending on existing knowledge, successful exploratory innovation requires their effective acquisition and assimilation of new external knowledge $[49,50]$. 
Meanwhile, exploitative innovation is based on existing know-how and is related to improving technologies that already exist. It is the result of deepening and expanding existing knowledge and experience. The acquisition and absorption of external knowledge may hinder employees' focus on the task or work of their organization, and this hinders their enterprise's effective transformation and use of knowledge. Therefore, we propose that potential absorptive capacity regulates both realized absorptive capacity and exploratory innovation, and that it limits both realized absorptive capacity and exploitative innovation.

Hypothesis 5a (H5a). Potential absorptive capacity augments realized absorptive capacity such that the two jointly have a negative impact on exploitative innovation.

Hypothesis $\mathbf{5 b} \mathbf{b} \mathbf{H} 5 \mathbf{b})$. Potential absorptive capacity augments realized absorptive capacity such that the two jointly have a positive impact on exploratory innovation.

\section{Research Methodology}

\subsection{Participants}

For this article, we found official information on China's high-tech enterprise certification organization (www.innocom.gov.cn, accessed on 6 September 2020). We identified 700 companies in China's Optics Valley, a famous high-tech industrial park in Middle China hosting many leading domestic pharmaceutical companies and optoelectronic information companies. Most of these companies are environmentally friendly enterprises committed to taking social responsibility through sustainable innovation. Environmentally friendly enterprises are those that meet the "Interpretation of the National Environmentally Friendly Enterprise Indicators" [51]. To achieve sustainable innovation, enterprises need to improve existing technologies, and at the same time explore new markets, develop new products, and obtain new opportunities through exploratory innovation. These factors allowed us to collect data on entrepreneurial organizations.

In total, we received 392 valid questionnaires from 700 submitted. The respondents were middle and senior managers, 89 of whom were responsible for R\&D departments. These executives had at least 2 years' experience in their current positions and were required to discuss their companies' markets and knowledge practices, including their own activities. The participants' characteristics are shown in Table A1. They represented high-tech companies of all kinds, $84 \%$ having been high-tech companies for at least 3 years and $43.7 \%$ having an average annual profit of CNY 50 million in 3 years. Some participants' institutions also had subsidiaries in other parts of China.

\subsection{Procedure}

Following the procedures followed in prior research [30,52], we developed questionnaires for research models and used existing tools to measure each construct. First, we adapted all the measurement items from the existing literature (see Table A2). A sevenpoint Likert scale was used to measure each reflective construct containing at least three items. Second, we hired a professional translator to translate the original English into Chinese. Then, we invited one native user of English with fluency in Chinese to translate it back. Our research team compared the two versions, evaluated the quality of the questionnaire, and made several modifications. Finally, we piloted the questionnaire over the phone with chairs at nine high-tech companies whose annual profits were more than USD 100 million. We fine-tuned the questionnaire according to their feedback.

We have taken several measures to ensure the statistical generalizability and validity of our sample. First, we obtained a list of 700 companies in China's Optics Valley from a business research company. We have carefully checked whether the companies on the list passed the ISO 14001 environmental management requirement, to confirm whether these companies are environmentally friendly. Optics Valley is an important high-tech development zone in China, which has incubated many enterprises. Samples from Optics Valley can provide us with data on different levels of entrepreneurial orientation and 
sustainable innovation. Second, we posted the questionnaire to managers and called them to ensure whether they had obtained and responded effectively to the questionnaire. Our response rate was $56 \%$, which is acceptable and could signify that our research has non-response bias [53]. Third, we also carried out a wave analysis to test for non-response bias, as the late responses were presumed to be similar to no responses [30]. To examine differences in key constructs between early and late responses, we performed a $t$-test. The results for entrepreneurial orientation $(p=0.42)$, exploratory $(p=0.10)$ and exploitative innovation $(p=0.99)$, and potential $(p=0.92)$ and realized absorptive capacity $(p=0.25)$ showed no significant differences between the two waves of respondents ( $p$ values derived from $t$ ). The $t$-test results show that our study is free from non-response bias. Finally, we used two methods to evaluate common method bias (CMB) in our research. On one hand, using the AMOS software package, we developed a model comprising one single factor with all the reflective measurement items. The model exhibited poor fit ( $\mathrm{RMSR}=0.114$, higher than 0.08; GIF = 0.55 lower than 0.9; AGFI = 0.502 lower than 0.9), indicating that $\mathrm{CMB}$ was not a threat for our study [53]. On the other hand, we evaluated all variance inflation factors (VIF) via a full collinearity test. The largest VIF was 2.01, indicating that our measurement model was not threatened by potential CMB [30].

\section{Results}

\subsection{Measurement Model}

In Table A3, the value of Cronbach's $\alpha$ for all variables was larger than 0.7 , while the composite reliability value for each variable was over 0.8 . Most of the standard loadings were above 0.7 . Table A3 shows descriptive statistics and a correlation matrix. It can be seen from the table that this study's measurement tool had good internal consistency and reliability. Specifically, this study adapted the scale of entrepreneurial orientation given by Hughes and Morgan [54]. Scholars highlight that in a given context, the dimensions of entrepreneurial orientation may vary independently of each other [28]. Therefore, prior empirical studies have tended to examine each sub-dimension within the entrepreneurial field. It is worth noting that risk-taking, innovation, enthusiasm, competitive radicalism, and autonomy are different structures. In addition, an independent examination of the evaluation dimensions of entrepreneurial orientation is helpful to evaluate situations in which the stability of the dimensions themselves or their relationships may change over time. As entrepreneurial orientation in our study was treated as a second-order reflective construct, we conducted a specific confirmatory factor analyses (CFA) model to assess its internal validity. The goodness fit of this CFA model for entrepreneurial orientation was measured as $\chi^{2} / d f=1.319$, with a root-mean-square error of approximation (RMSEA) of 0.026, a Tucker-Lewis index (TLI) of 0.983 , and a comparative fit index (CFI) of 0.986 . All fitting indexes were within the acceptable ranges, so the model was realistic and acceptable. All factor loads were greater than 0.5 , so the entrepreneurial derivative table had good structural validity.

\subsection{Hypothesis Testing}

To verify the relevant hypotheses in our framework, Mplus software was used to perform a modeling analysis on the hypothetical model. Figure 2 presents the standardized solution results of the hypothetical model. The fitting situation of the model was measured as $\chi^{2} / d f=2.487$, RMSEA $=0.057, \mathrm{CFI}=0.955$, and TLI $=0.874$. Besides TLI being slightly lower than 0.9 , the fitting indexes performed well; the model was acceptable.

Table 1 shows the standardized regression estimations, showing that the impacts of entrepreneurial orientation on potential $(\beta=0.110, p<0.05)$ and realized absorptive capacity $(\beta=0.160, p<0.05)$ were both positive and significant. Therefore, our results support $\mathrm{H} 1$ and $\mathrm{H} 2$. We also noticed that the impacts of potential absorptive capacity on exploitative $(\beta=0.198, p<0.001)$ and exploratory $(\beta=0.162, p<0.001)$ innovation were positive and significant, indicating that $\mathrm{H} 3 \mathrm{a}$ and $\mathrm{H} 3 \mathrm{~b}$ are supported. The same positive and 
significant effects on realized absorptive capacity were also identified ( $\beta_{\text {exploitative }}=0.224$, $\left.\beta_{\text {exploratory }}=0.223\right)$. Therefore $\mathrm{H} 4 \mathrm{a}$ and $\mathrm{b}$ are supported.

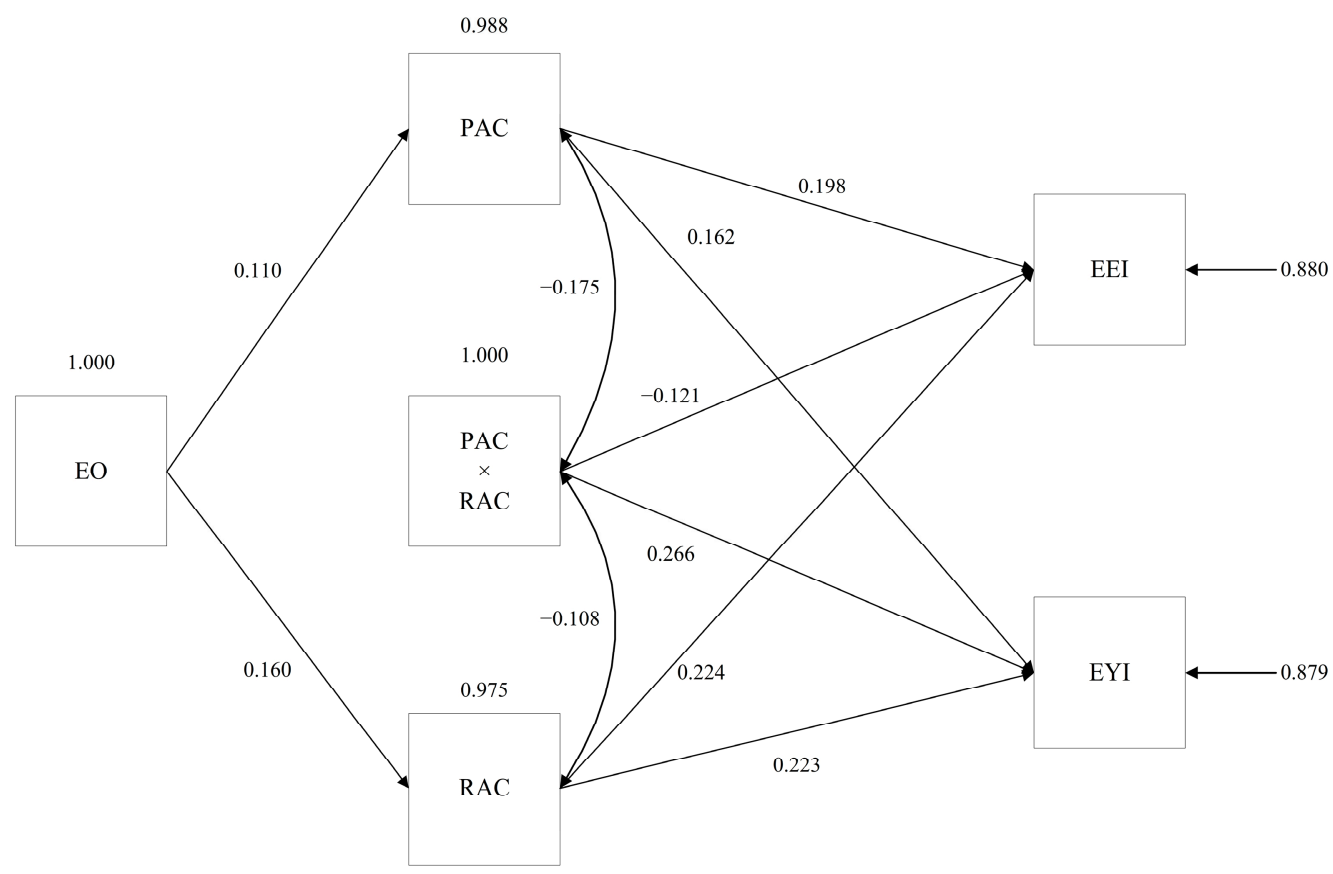

Figure 2. Results of SEM model (standardized estimate). Note: EO refers to entrepreneurial orientation; PAC and RAC refer to potential and realized absorptive capacity; EEI refers to exploitative innovation; EYI refers to exploratory innovation.

Table 1. Standardized regression estimations.

\begin{tabular}{cccccccc}
\hline & Path & & Original Estimate & Standardized Estimate & Standard Error & $t$ & $p$ \\
\hline EO & $\rightarrow$ & PAC & 0.134 & 0.110 & 0.056 & 2.397 & 0.017 \\
EO & $\rightarrow$ & RAC & 0.208 & 0.160 & 0.060 & 3.468 & 0.001 \\
PAC & $\rightarrow$ & EEI & 0.227 & 0.198 & 0.052 & 4.373 & $* * *$ \\
PAC & $\rightarrow$ & EYI & 0.158 & 0.162 & 0.044 & 3.579 & $* * *$ \\
RAC & $\rightarrow$ & EEI & 0.240 & 0.224 & 0.048 & 4.990 & $* * *$ \\
RAC & $\rightarrow$ & EYI & 0.204 & 0.223 & 0.041 & 4.984 & $* * *$ \\
PAC $\times$ RAC & $\rightarrow$ & EEI & -0.130 & -0.121 & 0.048 & -2.697 & 0.007 \\
PAC $\times$ RAC & $\rightarrow$ & EYI & 0.242 & 0.266 & 0.041 & 5.933 & $* * *$ \\
\hline
\end{tabular}

Note: ${ }^{* * *}$ Means $p<0.001$.

We see a slight difference when considering the interaction term of realized and potential absorptive capacity. The interaction term of realized and potential absorptive capacity showed a significantly negative level of path coefficient for exploitative innovation $(\beta=-0.121, p<0.05)$. The negative path coefficient shows that the joint effect of potential and realized absorptive capacity on exploitative innovation was less than the sum of their individual effects. The interactive effect of realized and potential absorptive capacity on the path coefficient for exploratory innovation reached a positive significant level $(\beta=0.266$, $p<0.05)$. The positive path coefficient highlights that the joint effect on exploitative innovation of realized and potential absorptive capacity was greater than the sum of their individual effects. Therefore, hypotheses $5 \mathrm{a}$ and $5 \mathrm{~b}$ are supported.

To test our results and take a further look at the interaction terms, we used PROCESS in SPSS to evaluate the conditional effects of absorptive capacity on coefficient paths between entrepreneurial orientation and the two types of innovation. Since in statistical models interaction and moderation are measured in the same way [55], we tested the 
conditional effects of realized and potential absorptive capacity in two separate models using PROCESS. The results, shown in Table 2, highlight that when potential absorptive capacity rises from 4.66 to 6.50 , the effect on exploitative innovation of realized absorptive capacity decreases from 0.36 to 0.11 ( $p>0.1$, not significant). This indicates a substitute relationship between the two types of absorptive capacity [56]. Meanwhile, we also noticed that the effect of realized absorptive capacity-that is, the capability to exploit external knowledge-on exploratory innovation increased from -0.03 ( $p>0.1$, not significant) to 0.43 . This indicates the two dimensions of absorptive capacity were complementary in this relationship. When observing the conditional effect changes of potential absorptive capacity, we derived the same result.

Table 2. Conditional effects at values of absorptive capacity.

\begin{tabular}{|c|c|c|c|c|c|c|}
\hline \multicolumn{7}{|c|}{ Effect of RAC on EEI } \\
\hline PAC & Effect & se & $t$ & $p$ & LLCI & ULCI \\
\hline 4.66 & 0.36 & 0.06 & 5.68 & 0.00 & 0.24 & 0.48 \\
\hline 5.67 & 0.23 & 0.05 & 4.54 & 0.00 & 0.13 & 0.32 \\
\hline 6.50 & 0.11 & 0.07 & 1.61 & 0.11 & -0.03 & 0.25 \\
\hline \multicolumn{7}{|c|}{ Effect of PAC on EEI } \\
\hline RAC & Effect & se & $t$ & $p$ & LLCI & ULCI \\
\hline 4.50 & 0.36 & 0.07 & 5.44 & 0.00 & 0.23 & 0.5 \\
\hline 5.67 & 0.21 & 0.05 & 3.87 & 0.00 & 0.10 & 0.31 \\
\hline 6.67 & 0.07 & 0.08 & 0.9 & 0.37 & -0.09 & 0.24 \\
\hline \multicolumn{7}{|c|}{ Effect of RAC on EYI } \\
\hline PAC & Effect & se & $t$ & $p$ & LLCI & ULCI \\
\hline 4.66 & -0.03 & 0.05 & -0.55 & 0.58 & -0.14 & 0.08 \\
\hline 5.67 & 0.22 & 0.04 & 5.23 & 0.00 & 0.14 & 0.3 \\
\hline 6.50 & 0.43 & 0.06 & 7.14 & 0.00 & 0.31 & 0.54 \\
\hline \multicolumn{7}{|c|}{ Effect of PAC on EYI } \\
\hline RAC & Effect & se & $t$ & $p$ & LLCI & ULCI \\
\hline 4.50 & -0.10 & 0.06 & -1.84 & 0.07 & -0.22 & 0.01 \\
\hline 5.67 & 0.18 & 0.05 & 4.04 & 0.00 & 0.09 & 0.27 \\
\hline 6.67 & 0.43 & 0.07 & 6.15 & 0.00 & 0.29 & 0.57 \\
\hline
\end{tabular}

We also tested the indirect effects of both types of absorptive capacity on the linkage of entrepreneurial orientation to innovation. The results shown in Table 3 highlight that only the indirect effects are significant, as their confidence intervals do not contain zero. The results reveal the full mediating roles of both types of absorptive capacity in the relationship between entrepreneurial orientation and both type of sustainable innovation.

Table 3. Direct and indirect effects of entrepreneurial orientation on innovation.

\begin{tabular}{|c|c|c|c|c|c|c|c|c|}
\hline \multirow[b]{2}{*}{ Mediator } & \multicolumn{4}{|c|}{ Direct Effect of EO on EEI } & \multicolumn{4}{|c|}{ Direct Effect of EO on EYI } \\
\hline & Effect & BootSE & BootLLCI & BootULCI & Effect & BootSE & BootLLCI & BootULCI \\
\hline PAC & 0.08 & 0.06 & -0.05 & 0.20 & 0.08 & 0.06 & -0.03 & 0.19 \\
\hline \multirow[t]{2}{*}{ RAC } & 0.06 & 0.06 & -0.07 & 0.18 & 0.06 & 0.06 & -0.05 & 0.17 \\
\hline & \multicolumn{4}{|c|}{ Indirect Effect of EO on EEI } & \multicolumn{4}{|c|}{ Indirect Effect of EO on EYI } \\
\hline Model & Effect & BootSE & BootLLCI & BootULCI & Effect & BootSE & BootLLCI & BootULCI \\
\hline PAC & 0.04 & 0.02 & 0.01 & 0.08 & 0.02 & 0.01 & 0.002 & 0.04 \\
\hline RAC & 0.06 & 0.02 & 0.02 & 0.11 & 0.04 & 0.01 & 0.02 & 0.07 \\
\hline
\end{tabular}




\section{Discussion and Implications}

These findings enrich the existing literature by showing how corporate strategies and capabilities match. Entrepreneurial orientation may promote absorptive capacity, thereby accelerating sustainable exploitation and exploration over time and inhibiting organizational inertia. These findings not only reveal the influence mechanism of entrepreneurial orientation on sustainable innovation [57], but also point out ways for startups to avoid failure when pursuing sustainable development. We believe corporate entrepreneurial orientation and absorptive capacity together constitute dynamic capabilities; companies can rely on this ability to cope with social responsibility [19]. We have thus supplemented empirical evidence in this field.

\subsection{Theoretical Implications}

First, this study introduces the perspective of absorptive capacity and explores the relationship between entrepreneurial orientation and sustainable innovation. As the evaluation criteria of sustainable innovation may be different in countries due to different degrees of spatial, temporal, and cultural embeddedness, research in developing countries usually studies the impact of policies on sustainable innovation from the perspective of stakeholders, while that in developed countries focuses on how to maintain competitiveness while carrying out sustainable innovation [58-60]. Therefore, it is necessary to investigate how to leverage entrepreneurial orientation for different types of sustainable innovation in the context of China. Believing that absorptive capacity is an important antecedent variable in the process of organizations' development of exploration and exploitation toward sustainable performance [61], we examined the linkage from entrepreneurial orientation to exploitation and exploration through empirical research. Prior research regarded absorptive capacity as a moderator in the relation between entrepreneurial orientation and innovation [13], and we found that entrepreneurial orientation is not bound to sustainable innovation in a simple linear relationship. As an organizational strategy, entrepreneurial orientation influences exploration and exploitation through the mediating effects of two types of absorptive capacity. In general, a positive correlation holds between entrepreneurial orientation and absorptive capacity, which has a positive impact on sustainable innovation.

Second, our results provide empirical evidence that, through absorptive capacity, entrepreneurial orientation is positively related to both types of sustainable innovation. Previous studies highlight the role of entrepreneurial orientation for sustainable innovation, in that a firm's risk-taking and openness is critical to sustainable innovation [59]. However, they did not address innovation, or analyze the different mechanisms shaping entrepreneurial orientation towards different types of innovation via absorptive capacity. The support of new processes built through exploration coincides with organizations' entrepreneurial orientation. In fact, due to organizational inertia, exploration is strongly resisted in organizations with deep-rooted experience [62]. A company with strong capabilities in its current field may rationally reduce its exploratory behavior due to complacency, incompatible technological paths, and cost considerations [63,64]. Even if an enterprise has an entrepreneurial orientation, its innovative, active risk-taking behavior may be ineffective unless it does have the absorptive capacity to integrate diverse knowledge. By actively acquiring and absorbing new market-related knowledge, it is possible to achieve a more effective transformation of entrepreneurial activities. Only when absorptive capacity improves can the acquiring and assimilating diverse external knowledge be promoted and exploratory innovation be strengthened [65].

Third, we separately examined the impacts of two types of absorptive capacity on sustainable innovation, including exploration and exploitation. Previous research has often treated absorptive capacity as a general capability [61], or regarded potential absorptive capacity as an antecedent of realized absorptive capacity [46]. We found that the interaction between realized and potential absorptive capacity has different effects. Regarding exploitative innovation, our results highlight that potential absorptive capacity augments realized absorptive capacity such that the two have a jointly positive impact on exploitative 
innovation. On the one hand, as organizations continue to acquire and use knowledge from outside and update their reserves of knowledge, potential absorptive capacity can enhance their ability to discover new ideas and innovation by transforming knowledge into the capacity for sustainable development. On the other hand, the transformation of knowledge enhances an organization's understanding of potential markets, promotes the integration of existing and new technologies in enterprise, and increases the certainty of exploratory innovation. We also find that potential absorptive capacity augments realized absorptive capacity, and that the two have a jointly negative impact on exploitative innovation. This may be because, although exploitative innovation needs to strengthen the flow of information between and within organizations and is more inclined to transform and use internal knowledge, acquiring and assimilating external knowledge promotes the flexible use and coordination of resources. Such use and coordination can support various technologies and products, so that companies can ease organizational inertia and easily switch to new platforms [66].

\subsection{Practical Implications}

First, our findings provide a deeper understanding of the linkage between entrepreneurial orientation and sustainable innovation. We have proposed to enrich the idea of using entrepreneurially oriented organizations' absorptive capacity to carry out sustainable innovation. Entrepreneurial orientation encourages organizations to invest in acquiring resources and applying knowledge for environmental process and product innovation [67], which are positively related to sustainable innovation performance [68]. To achieve sustainable innovation, organizations often face the dilemma of investing limited resources in the development of existing products or in exploring new products. Organizations should establish an effective system for transforming external support into internal knowledge to achieve sustainable development through resource and technology restructuring. Managers should realize that absorptive capacity helps organizations be flexible and apply diverse knowledge for exploitation and exploration.

Second, to balance exploratory and exploitative innovation, we suggest start-ups cultivate absorptive capacity and balance their innovation. Potential and realized absorptive capacities show a complementary effect on exploratory innovation, which then shows a substitutive effect on exploitative innovation. This result highlights that organizations could adjust their capabilities to absorb (as well as transform and apply) external knowledge to form different configurations of exploration and exploitation. On one hand, organizations should strengthen internal knowledge exchanges, introduce knowledge management mechanisms that adapt to sustainable innovation, and prevent organizations from blindly developing adventurous, innovative, and proactive behaviors [69]. On the other hand, organizations should establish the ability to acquire, absorb, and utilize new technology in the flexible allocation of knowledge resources [70], and provide knowledge guarantees for exploring unknown areas while avoiding the ability trap.

Third, high-tech enterprise entrepreneurship has the characteristics of high technology density, long R\&D cycles, large R\&D investments, and high returns on new products. To achieve sustainable innovation, organizations must consider both long-term and short-term returns. Entrepreneurially oriented organizations believe corporate competitive advantages stem from innovation and risky investment, and they advocate new opportunities to guide customer needs and pursuits [71]. Organizations can be brave enough to discover new opportunities while taking certain risks, and they can take advanced innovative actions to seize these opportunities [72]. However, the sustainable development of a company requires immediate business support. Absorptive capacity can help organizations, through the rapid absorption and transformation of knowledge, to issue innovative products that meet current market needs. Therefore, organizations with such characteristics must cultivate entrepreneurial orientation and absorptive capacity at the same time. On one hand, by supporting the development of existing technology, they obtain funds and keep 
the business going; on the other hand, by stimulating technological exploration, they ensure innovation in the long-term sustainable development of the enterprise.

Fourth, our results also imply that the government can promote sustainable innovation from multiple perspectives. On the one hand, the government can improve the absorptive capacity of enterprises by encouraging the upgrading of industrial clusters and integrating enterprises at different locations of the industrial chain. On the other hand, the government could encourage enterprises to develop an entrepreneurial orientation for green transformation. The government needs to help companies recognize the importance of long-term benefits, promote the flow of knowledge between companies, and strengthen various means of absorptive capacity building. Only in this way can resources be optimally used, and the goal of carbon neutrality be achieved.

\subsection{Limitations and Directions for Future Research}

First, our sample size is limited. Larger sample sizes across different regions may supply greater statistical power. Second, we used cross-sectional data, thus limiting the causal inference between entrepreneurial orientation and sustainable innovation. As we explained, a longitudinal study could extend our work in understanding how to further balance the exploration and development related to entrepreneurial orientation and absorptive capacity. Third, respondents at different organizational levels may deviate in their evaluations of entrepreneurial orientation and other variables. A future pair-matched survey, in which supervisors could answer questions about entrepreneurial orientation and senior managers with relevant experience could answer other questions, would supply more ideal results.

The current study highlights directions for future research. First, the results, based on a general view of organizational inertia, highlight the different potential routes from entrepreneurial orientation to sustainable innovation. Future research could investigate and evaluate the specific organizational inertia in a given environment, such as green transformation. Second, innovation involves more factors than those in our model, especially in the digital era and the green-oriented business world. Further research could extend our model with the consideration of digital or green entrepreneurial orientation. Finally, from the perspective of system dynamics, we believe organizations' innovation may adversely affect entrepreneurial orientation. Future researchers should pay attention to the interaction and evolution of independent variables of sustainable entrepreneurial orientation and sustainable innovation.

\section{Conclusions}

In the context of sustainable development, we combine views of organizational inertia and absorptive capacity to investigate the relationships between entrepreneurial orientation and two types of sustainable innovation. Our research fills the existing gap in the relevant literature, as there is currently insufficient evidence concerning Chinese firms' sustainable innovation practices. Our study probed into innovation and absorptive capacity, and analyzed the different mechanisms shaping different types of innovation. With the data set of 392 Chinese environmentally friendly companies, we have empirically verified that entrepreneurial orientation enhances a firms' integration of its existing knowledge with the acquirement of external knowledge, thereby improving both exploratory and exploitative innovation. We have also discovered the mediating role of both potential and realized absorptive capacity in those relationships. In further analyses, the interaction effects of the two absorptive capacities different for the two types of sustainable innovation. The effect was negative for exploitative innovation but positive for exploratory innovation. The results indicate that potential absorptive capacity and realized absorptive capacity are substitutive to exploitative innovation and complementary to exploratory innovation. This in-depth analysis will help organizations to distribute their resources more effectively, build capabilities, and achieve the required innovations. 
Author Contributions: Conceptualization, L.Y., Z.W. and H.M.; methodology, H.M.; software, H.M.; validation, H.M. and L.Y.; formal analysis, L.Y.; investigation, L.Y.; resources, L.Y.; data curation, H.M.; writing — original draft preparation, L.Y.; writing—review and editing, H.M.; All authors have read and agreed to the published version of the manuscript.

Funding: This work was supported by the National Natural Science Foundation (NSFC) Programs of China [72061005,71661017], Huazhong University of Science and Technology Special Funds for Development of Humanities and Social Sciences, Guizhou Science and Technology Foundation Program of China ([2020]1Y285), Startup Foundation for Distinguished Scholars of Guizhou University of Finance and Economics (2019YJ065), and Guizhou Province Higher Education Teaching Content and Curriculum System Reform Project (2019076).

Institutional Review Board Statement: Not applicable.

Informed Consent Statement: Not applicable.

Data Availability Statement: Not applicable.

Conflicts of Interest: The authors declare no conflict of interest.

\section{Appendix A}

Table A1. Sample profile.

\begin{tabular}{cccc}
\hline Characteristic & Range & Frequency & Percentage \\
\hline & Software & 56 & $14.3 \%$ \\
& Mobile Communication Industry & 47 & $12.0 \%$ \\
Industry sector & Medical Industry & 102 & $26.0 \%$ \\
& Biotech Industry & 83 & $21.2 \%$ \\
& Internet Industry & 64 & $16.3 \%$ \\
& Material Industry & 40 & $10.2 \%$ \\
\hline \multirow{3}{*}{ Organization age } & $\leq 5$ & 42 & $10.7 \%$ \\
(year) & $6-10$ & 280 & $71.4 \%$ \\
& $11-20$ & 65 & $16.7 \%$ \\
& $>20$ & 5 & $1.2 \%$ \\
\hline Organization size & $\leq 50$ & 27 & $6.9 \%$ \\
(Number of & $51-100$ & 78 & $19.9 \%$ \\
employees) & $101-200$ & 212 & $54.1 \%$ \\
& $201-500$ & 59 & $15.1 \%$ \\
& $501-1000$ & 8 & $2.0 \%$ \\
& $>1000$ & 8 & $2.0 \%$ \\
\hline
\end{tabular}

Table A2. Constructs and measures.

\begin{tabular}{|c|c|c|c|}
\hline $\begin{array}{l}\text { Constructs } \\
\text { (Items) }\end{array}$ & Measurement & $\begin{array}{l}\text { Standard } \\
\text { Loadings }\end{array}$ & Reference \\
\hline \multicolumn{3}{|c|}{ Exploitative Innovation (EEI) (Cronbach's $\alpha=0.848, \mathrm{CR}=0.891$ ) } & \multirow{7}{*}{ Adapted from ref. $[4,73]$} \\
\hline \multicolumn{3}{|c|}{ In the new product development processes, to what extent has your firm } & \\
\hline EEI1 & Upgraded current knowledge for familiar products. & 0.700 & \\
\hline EEI2 & $\begin{array}{l}\text { Invested in exploiting mature technologies that improve the } \\
\text { productivity of current innovation operations. }\end{array}$ & 0.732 & \\
\hline EEI3 & $\begin{array}{l}\text { Enhanced abilities in searching for solutions to customer } \\
\text { problems that are near to existing solutions. }\end{array}$ & 0.749 & \\
\hline EEI4 & $\begin{array}{l}\text { Upgraded skills in product development processes in which the } \\
\text { firm already possesses rich experience. }\end{array}$ & 0.686 & \\
\hline EEI5 & $\begin{array}{c}\text { Strengthened knowledge and skills to improve the efficiency of } \\
\text { existing innovation activities. }\end{array}$ & 0.766 & \\
\hline
\end{tabular}


Table A2. Cont.

\begin{tabular}{|c|c|c|c|}
\hline $\begin{array}{l}\text { Constructs } \\
\text { (Items) }\end{array}$ & Measurement & $\begin{array}{l}\text { Standard } \\
\text { Loadings }\end{array}$ & Reference \\
\hline \multicolumn{3}{|c|}{ Exploratory innovation (EYI) (Cronbach's $\alpha=0.790, \mathrm{CR}=0.854$ ) } & \multirow{7}{*}{ Adapted from ref. $[4,73]$} \\
\hline \multicolumn{3}{|c|}{ In the new product development processes, to what extent has your firm } & \\
\hline EYI1 & $\begin{array}{l}\text { Acquired manufacturing technologies and skills entirely new to } \\
\text { the firm. }\end{array}$ & 0.674 & \\
\hline EYI2 & $\begin{array}{l}\text { Learned product development skills and processes entirely new } \\
\text { to the industry. }\end{array}$ & 0.703 & \\
\hline EYI3 & $\begin{array}{l}\text { Acquired entirely new managerial and organizational skills that } \\
\text { are important for innovation. }\end{array}$ & 0.642 & \\
\hline EYI4 & $\begin{array}{l}\text { Learned totally new skills in funding new technology and } \\
\text { training R\&D personnel. }\end{array}$ & 0.648 & \\
\hline EYI5 & $\begin{array}{l}\text { Strengthened innovation skills in areas where it has no prior } \\
\text { experience. }\end{array}$ & 0.608 & \\
\hline \multicolumn{3}{|c|}{ Potential absorptive capacity (PAC) (Cronbach's $\alpha=0.763, \mathrm{CR}=0.834$ ) } & \multirow{13}{*}{ Adapted from ref. $[29,30]$} \\
\hline PAC1 & We are successful in learning new things. & 0.688 & \\
\hline PAC2 & $\begin{array}{l}\text { We are effective in developing new knowledge or insights that } \\
\text { have the potential to influence product/service development. }\end{array}$ & 0.772 & \\
\hline PAC3 & $\begin{array}{l}\text { We are able to identify and acquire internal (e.g., within the } \\
\text { firm) and external (e.g., market) knowledge. }\end{array}$ & 0.766 & \\
\hline PAC4 & $\begin{array}{l}\text { We have effective routines to identify, value, and import new } \\
\text { information and knowledge from channel partners. }\end{array}$ & 0.692 & \\
\hline PAC5 & $\begin{array}{l}\text { We have adequate routines to analyze the information and } \\
\text { knowledge obtained. }\end{array}$ & 0.740 & \\
\hline PAC6 & $\begin{array}{l}\text { We have adequate routines to assimilate new information and } \\
\text { knowledge. }\end{array}$ & 0.717 & \\
\hline \multicolumn{3}{|c|}{ Realized Absorptive Capacity (RAC) (Cronbach's $\alpha=0.797, \mathrm{CR}=0.800$ ) } & \\
\hline RAC1 & $\begin{array}{l}\text { We can successfully integrate our existing knowledge with the } \\
\text { new information and knowledge acquired. }\end{array}$ & 0.755 & \\
\hline RAC2 & $\begin{array}{l}\text { We are effective in transforming existing information into new } \\
\text { knowledge. }\end{array}$ & 0.738 & \\
\hline RAC3 & $\begin{array}{l}\text { We can successfully grasp the opportunities for our firm from } \\
\text { new external knowledge. }\end{array}$ & 0.748 & \\
\hline RAC4 & $\begin{array}{l}\text { We can successfully transform he new integrated information } \\
\text { and knowledge into concrete applications. }\end{array}$ & 0.694 & \\
\hline RAC5 & We are effective in utilizing knowledge in new products. & 0.749 & \\
\hline RAC6 & We constantly consider better ways to exploit knowledge. & 0.796 & \\
\hline \multicolumn{3}{|c|}{ Entrepreneurial Orientation (EO) } & \multirow{7}{*}{ Adapted from ref. $[20,54]$} \\
\hline \multicolumn{3}{|c|}{ Risk-taking (Cronbach's $\alpha=0.777, \mathrm{CR}=0.870$ ) } & \\
\hline EORT1 & $\begin{array}{l}\text { The term "risk taker" is considered a positive attribute for } \\
\text { people in our business. }\end{array}$ & 0.744 & \\
\hline EORT2 & $\begin{array}{l}\text { People in our business are encouraged to take calculated risks } \\
\text { with new ideas. }\end{array}$ & 0.733 & \\
\hline EORT3 & $\begin{array}{l}\text { Our business emphasizes both exploration and experimentation } \\
\text { for opportunities. }\end{array}$ & 0.723 & \\
\hline \multicolumn{3}{|c|}{ Innovation (Cronbach's $\alpha=0.778, \mathrm{CR}=0.871$ ) } & \\
\hline EOI1 & $\begin{array}{c}\text { We actively introduce improvements and innovations in our } \\
\text { business. }\end{array}$ & 0.678 & \\
\hline
\end{tabular}


Table A2. Cont.

\begin{tabular}{|c|c|c|c|}
\hline $\begin{array}{l}\text { Constructs } \\
\text { (Items) }\end{array}$ & Measurement & $\begin{array}{l}\text { Standard } \\
\text { Loadings }\end{array}$ & Reference \\
\hline EOI 2 & Our business is creative in its methods of operation. & 0.715 & \\
\hline EOI 3 & Our business seeks out new ways to do things. & 0.811 & \\
\hline \multicolumn{3}{|c|}{ Enthusiasm (Cronbach's $\alpha=0.786, \mathrm{CR}=0.875)$} & \\
\hline EOP1 & $\begin{array}{l}\text { We always try to take the initiative in every situation (e.g., } \\
\text { against competitors, in projects when working with others). }\end{array}$ & 0.746 & \\
\hline EOP2 & We excel at identifying opportunities. & 0.734 & \\
\hline EOP3 & We initiate actions to which other organizations respond. & 0.746 & \\
\hline \multicolumn{3}{|c|}{ Competitive Radicality (Cronbach's $\alpha=0.783, \mathrm{CR}=0.874$ ) } & \\
\hline EOCA1 & Our business is intensely competitive. & 0.752 & \\
\hline EOCA2 & $\begin{array}{l}\text { In general, our business takes a bold or aggressive approach } \\
\text { when competing. }\end{array}$ & 0.741 & \\
\hline EOCA3 & $\begin{array}{l}\text { We try to outdo and out-maneuver the competition as best as } \\
\text { we can. }\end{array}$ & 0.723 & \\
\hline \multicolumn{3}{|c|}{ Autonomy(Cronbach's $\alpha=0.862, \mathrm{CR}=0.897)$} & \\
\hline EOA1 & Employees are permitted to act and think without interference. & 0.760 & \\
\hline EOA2 & $\begin{array}{l}\text { Employees perform jobs that allow them to make and instigate } \\
\text { changes in the way they perform their work tasks. }\end{array}$ & 0.706 & \\
\hline EOA3 & $\begin{array}{l}\text { Employees are given freedom and independence to decide on } \\
\text { their own how to go about doing their work. }\end{array}$ & 0.691 & \\
\hline EOA4 & $\begin{array}{l}\text { Employees are given freedom to communicate without } \\
\text { interference. }\end{array}$ & 0.749 & \\
\hline EOA5 & $\begin{array}{l}\text { Employees are given authority and responsibility to act alone if } \\
\text { they think it to be in the best interests of the business. }\end{array}$ & 0.668 & \\
\hline EOA6 & Employees have access to all vital information. & 0.714 & \\
\hline
\end{tabular}

Table A3. Descriptive statistics and correlation matrix.

\begin{tabular}{|c|c|c|c|c|c|c|c|}
\hline Variables & Mean Value & Standard Deviation & EO & PAC & RAC & EEI & EYI \\
\hline $\mathrm{EO}$ & 5.518 & 0.782 & 1 & & & & \\
\hline PAC & 5.583 & 0.954 & $0.112 *$ & 1 & & & \\
\hline RAC & 5.547 & 1.019 & $0.161^{* *}$ & $0.167^{* *}$ & 1 & & \\
\hline EEI & 5.476 & 1.102 & 0.083 & $0.257 * *$ & $0.271^{* *}$ & 1 & \\
\hline EYI & 5.749 & 0.931 & 0.082 & $0.148 * *$ & $0.214^{* *}$ & 0.013 & 1 \\
\hline
\end{tabular}

Note: ${ }^{*} p<0.05,{ }^{* *} p<0.01$.

\section{References}

1. Cillo, V.; Petruzzelli, A.M.; Ardito, L.; Del Giudice, M. Understanding sustainable innovation: A systematic literature review. Corp. Soc. Responsib. Environ. Manag. 2019, 26, 1012-1025. [CrossRef]

2. Levinthal, D.A.; March, J.G. The myopia of learning. Strateg. Manag. J. 2010, 14, 95-112. [CrossRef]

3. Eisenhardt, K.M.; Furr, N.R.; Bingham, C. CROSSROADS-Microfoundations of Performance: Balancing Efficiency and Flexibility in Dynamic Environments. Organ. Sci. 2010, 21, 1263-1273. [CrossRef]

4. Tao, C.; Qu, Y.; Ren, H.; Guo, Z. The Influence of Inter-Enterprise Knowledge Heterogeneity on Exploratory and Exploitative Innovation Performance: The Moderating Role of Trust and Contract. Sustainability 2020, 12, 5677. [CrossRef]

5. He, P.; Pei, Y.; Lin, C.; Ye, D. Ambidextrous Marketing Capabilities, Exploratory and Exploitative Market-Based Innovation, and Innovation Performance: An Empirical Study on China's Manufacturing Sector. Sustainability 2021, 13, 1146. [CrossRef]

6. Rumelt, R.P. How much does industry matter? Strateg. Manag. J. 2010, 12, 167-185. [CrossRef]

7. Garcia, R.; Calantone, R.; Levine, R. The Role of Knowledge in Resource Allocation to Exploration versus Exploitation in Technologically Oriented Organizations. Decis. Sci. 2010, 34, 323-349. [CrossRef] 
8. Khan, A.; Chen, L.-R.; Hung, C.-Y. The Role of Corporate Social Responsibility in Supporting Second-Order Social Capital and Sustainable Innovation Ambidexterity. Sustainability 2021, 13, 6994. [CrossRef]

9. Arzubiaga, U.; Kotlar, J.; Massis, A.D.; Maseda, A.; Iturralde, T. Entrepreneurial orientation and innovation in family SMEs: Unveiling the (actual) impact of the Board of Directors. J. Bus. Ventur. 2018, 33, 455-469. [CrossRef]

10. Ilyas, G.B.; Munir, A.R.; Sobarsyah, M. Role of Strategic Leadership, Entrepreneurial Orientation, and Innovation on Small and Medium Enterprises Performance. Int. J. Econ. Res. 2017, 14, 61-72.

11. Covin, J.G.; Lumpkin, G.T. Entrepreneurial orientation theory and research: Reflections on a needed construct. Entrep. Theory Pract. 2011, 35, 855-872. [CrossRef]

12. Ferreira, J.; Coelho, A.; Moutinho, L. Dynamic capabilities, creativity and innovation capability and their impact on competitive advantage and firm performance: The moderating role of entrepreneurial orientation. Technovation 2020, 92, 102061. [CrossRef]

13. Zhai, Y.-M.; Sun, W.-Q.; Tsai, S.-B.; Wang, Z.; Zhao, Y.; Chen, Q. An empirical study on entrepreneurial orientation, absorptive capacity, and SMEs' innovation performance: A sustainable perspective. Sustainability 2018, 10, 314. [CrossRef]

14. Bhatt, G.D. Knowledge management in organizations: Examining the interaction between technologies, techniques, and people. J. Knowl. Manag. 2001, 5, 68-75. [CrossRef]

15. García-Lillo, F.; úbeda-García, M.; Marco-Lajara, B. Organizational ambidexterity: Exploring the knowledge base. Scientometrics 2016, 107, 1021-1040. [CrossRef]

16. Benner, M.J.; Tushman, M.L. Reflections on the 2013 Decade Award—“Exploitation, exploration, and process management: The productivity dilemma revisited" ten years later. Acad. Manag. Rev. 2015, 40, 497-514. [CrossRef]

17. March, L. Special Issue: Organizations, Decision Making and Strategy. The Myopia of Learning. Strateg. Manag. J. 1993, 14, 95-112.

18. Tzokas, N.; Kim, Y.A.; Akbar, H.; Al-Dajani, H. Absorptive capacity and performance: The role of customer relationship and technological capabilities in high-tech SMEs. Ind. Mark. Manag. 2015, 47, 134-142. [CrossRef]

19. Martin, E. Special Issue: The Evolution of Firm Capabilities. Dynamic Capabilities: What Are They? Strateg. Manag. J. 2000, 21, 1105-1121.

20. Mostafiz, M.I.; Hughes, M.; Sambasivan, M. Entrepreneurial Orientation, Competitive Advantage and Strategic Knowledge Management Capability in Malaysian Family Firms. J. Knowl. Manag. 2021. [CrossRef]

21. Ferreira, J.J.; Azevedo, S.G.; Ortiz, R.F. Contribution of resource-based view and entrepreneurial orientation on small firm growth. Cuad. Gestión 2011, 11, 95-116. [CrossRef]

22. Moss, T.W.; Neubaum, D.O.; Meyskens, M. The Effect of Virtuous and Entrepreneurial Orientations on Microfinance Lending and Repayment: A Signaling Theory Perspective. Entrep. Theory Pract. 2015, 39, 27-52. [CrossRef]

23. Arunachalam, S.; Ramaswami, S.N.; Herrmann, P.; Walker, D. Innovation pathway to profitability: The role of entrepreneurial orientation and marketing capabilities. J. Acad. Mark. 2018, 46, 1-23.

24. AlTaweel, I.R.; Al-Hawary, S.I. The Mediating Role of Innovation Capability on the Relationship between Strategic Agility and Organizational Performance. Sustainability 2021, 13, 7564. [CrossRef]

25. Wang, C.; Rodan, S.; Fruin, M.; Xu, X. Knowledge Networks, Collaboration Networks, and Exploratory Innovation. Acad. Manag. J. 2014, 57, 484-514. [CrossRef]

26. Mikalef, P.; van de Wetering, R.; Krogstie, J. Building dynamic capabilities by leveraging big data analytics: The role of organizational inertia. Inf. Manag. 2020, 58, 103412. [CrossRef]

27. Papachroni, A.; Heracleous, L.; Paroutis, S. In pursuit of ambidexterity: Managerial reactions to innovation-Efficiency tensions. Hum. Relat. 2016, 69, 1791-1822. [CrossRef]

28. Lumpkin, G.T.; Dess, G.G. Linking two dimensions of entrepreneurial orientation to firm performance: The moderating role of environment and industry life cycle. J. Bus. Ventur. 2001, 16, 429-451. [CrossRef]

29. Zahra, S.A.; George, G. The Net-Enabled Business Innovation Cycle and the Evolution of Dynamic Capabilities. Inf. Syst. Res. 2002, 13, 147-150. [CrossRef]

30. Mao, H.; Liu, S.; Zhang, J.; Zhang, Y.; Gong, Y. Information technology competency and organizational agility: Roles of absorptive capacity and information intensity. Inf. Technol. People 2021, 34, 421-451. [CrossRef]

31. Donate, M.J.; Sánchez, D. The role of knowledge-oriented leadership in knowledge management practices and innovation. J. Bus. Res. 2015, 68, 360-370. [CrossRef]

32. Teece, D.J.; Pisano, G.; Shuen, A. Dynamic capabilities and strategic management. Strateg. Manag. J. 1997, 18, 509-533. [CrossRef]

33. Swoboda, B.; Olejnik, E. Linking processes and dynamic capabilities of international SMEs: The mediating effect of international entrepreneurial orientation. J. Small Bus. Manag. 2016, 54, 139-161. [CrossRef]

34. Mapalala, M.J. Examining the Relationship between Entrepreneurial Orientation and Organizational Performance: The Moderating Role of Organizational Learning. Ph.D. Thesis, Regent University, Virginia Beach, VA, USA, 2017.

35. Covin, J.G.; Wales, W.J. The Measurement of Entrepreneurial Orientation. Entrep. Theory Pract. 2012, 36, 677-702. [CrossRef]

36. Limaj, E.; Bernroider, E.W. The roles of absorptive capacity and cultural balance for exploratory and exploitative innovation in SMEs. J. Bus. Res. 2019, 94, 137-153. [CrossRef]

37. Li, Y.H.; Huang, J.W.; Tsai, M.T. Entrepreneurial orientation and firm performance: The role of knowledge creation process. Ind. Mark. Manag. 2009, 38, 440-449. [CrossRef] 
38. Liao, J.; Welsch, H.; Stoica, M. Organizational Absorptive Capacity and Responsiveness: An Empirical Investigation of GrowthOriented SMEs. Entrep. Theory Pract. 2010, 28, 63-86. [CrossRef]

39. Shepherd, D.A.; Patzelt, H. The "heart" of entrepreneurship: The impact of entrepreneurial action on health and health on entrepreneurial action. J. Bus. Ventur. Insights 2015, 4, 22-29. [CrossRef]

40. Keh, H.T.; Nguyen, T.; Ng, H.P. The effects of entrepreneurial orientation and marketing information on the performance of SMEs. J. Bus. Ventur. 2007, 22, 592-611. [CrossRef]

41. Looy, B.V.; Martens, T.; Debackere, K. Organizing for Continuous Innovation: On the Sustainability of Ambidextrous Organizations. Creat. Innov. Manag. 2010, 14, 208-221. [CrossRef]

42. García-Sánchez, E.; García-Morales, V.J.; Martín-Rojas, R. Influence of technological assets on organizational performance through absorptive capacity, organizational innovation and internal labour flexibility. Sustainability 2018, 10, 770. [CrossRef]

43. Lieberman, M.B.; Montgomery, D.B. First-mover (dis)advantages: Retrospective and link with the resource-based view. Strateg. Manag. J. 1998, 19, 1111-1125. [CrossRef]

44. Krylova, K.O.; Vera, D.; Crossan, M. Knowledge transfer in knowledge-intensive organizations: The crucial role of improvisation in transferring and protecting knowledge. J. Knowl. Manag. 2016, 20, 1045-1064. [CrossRef]

45. Schot, J.; Steinmueller, W.E. Three frames for innovation policy: R\&D, systems of innovation and transformative change. Res. Policy 2018, 47, 1554-1567.

46. Leal-Rodríguez, A.L.; Roldán, J.L.; Ariza-Montes, J.A.; Leal-Millán, A. From potential absorptive capacity to innovation outcomes in project teams: The conditional mediating role of the realized absorptive capacity in a relational learning context. Int. J. Proj. Manag. 2014, 32, 894-907. [CrossRef]

47. Yeoh, P.-L. Realized and potential absorptive capacity: Understanding their antecedents and performance in the sourcing context. J. Mark. Theory Pract. 2009, 17, 21-36. [CrossRef]

48. Alexandre, R. Organizational Ambidexterity. Ambidexterity in Technology Sourcing: The Moderating Role of Absorptive Capacity. Organ. Sci. 2009, 20, 759-780.

49. McGrath, R. Management's three eras: A brief history. Harv. Bus. Rev. 2014, 30, $2-4$.

50. Kogut, B.; Zander, U. Knowledge of the Firm, Combinative Capabilities, and the Replication of Technology. Organ. Sci. 1992, 3 , 383-397. [CrossRef]

51. National Environmental Protection Administration. Index Explanation of National Environmental Friendly Enterprises. 2003. Available online: http://sthjt.hubei.gov.cn/fbjd/zc/zcwj/sthjbwj/200710/t20071015_1770251.shtml (accessed on 3 November 2020).

52. Liu, S.; Wang, L.; Huang, W.W. Effects of process and outcome controls on business process outsourcing performance: Moderating roles of vendor and client capability risks. Eur. J. Oper. Res. 2017, 260, 1115-1128. [CrossRef]

53. Lu, Y.; Ramamurthy, K. Understanding the link between information technology capability and organizational agility: An empirical examination. MIS Q. 2011, 35, 931-954. [CrossRef]

54. Hughes, M.; Hughes, P.; Morgan, R.E. Exploitative learning and entrepreneurial orientation alignment in emerging young firms: Implications for market and response performance. Br. J. Manag. 2007, 18, 359-375. [CrossRef]

55. Hayes, A.F. Introduction to Mediation, Moderation, and Conditional Process Analysis: A Regression-Based Approach; Guilford Publications: New York, NY, USA, 2017.

56. Titah, R.; Barki, H. Nonlinearities between attitude and subjective norms in information technology acceptance: A negative synergy? MIS Q. 2009, 33, 827-844. [CrossRef]

57. Rosenkopf, L.; Nerkar, A. Beyond local search: Boundary-spanning, exploration, and impact in the optical disk industry. Strateg. Manag. J. 2001, 22, 287-306. [CrossRef]

58. Boons, F.; Montalvo, C.; Quist, J.; Wagner, M. Sustainable innovation, business models and economic performance: An overview. J. Clean. Prod. 2013, 45, 1-8. [CrossRef]

59. Costa, J.; Matias, J.C. Open innovation 4.0 as an enhancer of sustainable innovation ecosystems. Sustainability $2020,12,8112$. [CrossRef]

60. Bacinello, E.; Tontini, G.; Alberton, A. Influence of maturity on corporate social responsibility and sustainable innovation in business performance. Corp. Soc. Responsib. Environ. Manag. 2020, 27, 749-759. [CrossRef]

61. Seo, Y.W.; Chae, S.W.; Lee, K.C. The impact of absorptive capacity, exploration, and exploitation on individual creativity: Moderating effect of subjective well-being. Comput. Hum. Behav. 2015, 42, 68-82. [CrossRef]

62. Zhen, J.; Cao, C.; Qiu, H.; Xie, Z. Impact of organizational inertia on organizational agility: The role of IT ambidexterity. Inf. Technol. Manag. 2021, 22, 1-13. [CrossRef]

63. Levinthal, C. Absorptive Capacity: A New Perspective on Learning and Innovation. Adm. Sci. Q. 1990, 35, 128-152.

64. Shen, J.; Sha, Z.; Wu, Y.J. Enterprise adaptive marketing capabilities and sustainable innovation performance: An opportunityresource integration perspective. Sustainability 2020, 12, 469. [CrossRef]

65. Cassiman, B.; Veugelers, R. In search of complementarity in innovation strategy: Internal R\&D and external knowledge acquisition. Oper. Res. 2006, 52, 68-82.

66. Berghman, L.; Matthyssens, P.; Vandenbempt, K. Value innovation, deliberate learning mechanisms and information from supply chain partners. Ind. Mark. Manag. 2012, 41, 27-39. [CrossRef] 
67. Pearce, J.A.; Fritz, D.A.; Davis, P.S. Entrepreneurial Orientation and the Performance of Religious Congregations as Predicted by Rational Choice Theory. Entrep. Theory Pract. 2010, 34, 219-248. [CrossRef]

68. Skordoulis, M.; Ntanos, S.; Kyriakopoulos, G.L.; Arabatzis, G.; Galatsidas, S.; Chalikias, M. Environmental innovation, open innovation dynamics and competitive advantage of medium and large-sized firms. J. Open Innov. Technol. Mark. Complex. 2020, 6, 195. [CrossRef]

69. Miguélez, E.; Moreno, R. Knowledge flows and the absorptive capacity of regions. Res. Policy 2015, 44, 833-848. [CrossRef]

70. Autor, D.; Dorn, D.; Hanson, G.; Li, L. Understanding regional export growth in China. In World Trade Evolution; Routledge: London, UK, 2018; pp. 195-228.

71. Chen, Y.-C.; Li, P.-C.; Evans, K.R. Effects of interaction and entrepreneurial orientation on organizational performance: Insights into market driven and market driving. Ind. Mark. Manag. 2012, 41, 1019-1034. [CrossRef]

72. Dess, G.G.; Lumpkin, G.T. The role of entrepreneurial orientation in stimulating effective corporate entrepreneurship. Acad. Manag. 2005, 19, 147-156. [CrossRef]

73. Atuahene-Gima, K. Resolving the capability—Rigidity paradox in new product innovation. J. Mark. 2005, 69, 61-83. [CrossRef] 